\title{
OPEN Publisher Correction: Guest Edited Collection: Gravitational biology and space medicine
}

\section{Daniela Grimm}

Correction to: Scientific Reports https://doi.org/10.1038/s41598-019-51231-8, published online 08 October 2019

In this Editorial, the Author Contribution, Competing Interests and Acknowledgments sections were omitted.

The Author Contributions section should read:

"D.G. wrote the invited editorial."

The Competing Interests section should read:

“The author declares no competing financial or non-financial interests."

The Acknowledgements section should read:

"The author was supported by the German Space Agency (DLR, grants 50WB1524 and 50WB1924) and Aarhus University. I would like to thank Dr. Marcus Krüger for preparing Figure 1 and for his help with Endnote. Moreover, I would like to thank the team of PRS \& EJE (Letchworth Garden City, UK) for academic proofreading of the manuscript."

(i) Open Access This article is licensed under a Creative Commons Attribution 4.0 International License, which permits use, sharing, adaptation, distribution and reproduction in any medium or format, as long as you give appropriate credit to the original author(s) and the source, provide a link to the Creative Commons license, and indicate if changes were made. The images or other third party material in this article are included in the article's Creative Commons license, unless indicated otherwise in a credit line to the material. If material is not included in the article's Creative Commons license and your intended use is not permitted by statutory regulation or exceeds the permitted use, you will need to obtain permission directly from the copyright holder. To view a copy of this license, visit http://creativecommons.org/licenses/by/4.0/.

(c) The Author(s) 2019 